\title{
New record of Squalus cubensis Howell Rivero, 1936 (Chondrichthyes, Squalidae) in Colombia
}

\author{
Diana María Orozco-Velásquez ${ }^{1, *}$, Fabio Gómez-Delgado ${ }^{1}$
}

\begin{abstract}
Edited by
Juan Carlos Salcedo-Reyes

(salcedo.juan@javeriana.edu.co)

1. Pontificia Universidad Javeriana.

Unidad de Ecología y Sistemática

UNESIS. Departamento de Biología.

Facultad de Ciencias. Pontificia

Universidad Javeriana, Bogotá D.C.

Colombia.

*ictiologa3007@yahoo.es

Received: $07-05-2015$

Accepted: 31-05-2016

Published on line: 17-06-2016

Citation: Orozco-Velásquez DM, Gómez-Delgado F. New record of Squalus cubensis Howell Rivero, 1936 (Chondrichthyes, Squalidae) in Colombia, Universitas Scientiarum, 21 (2): 159-166, 2016.

doi: 10.11144/Javeriana.SC21-2.nros
\end{abstract}

Funding: Shark Research Group of the Pontificia Universidad Javeriana.

Electronic supplementary material: $\mathrm{N} / \mathrm{A}$

OPEN ACCESS

\begin{abstract}
Two Cuban dogfish Squalus cubensis (Squalidae) are recorded for the first time in the area of influence of Isla Fuerte, an island located at the limit of the southern continental shelf of the Colombian Caribbean. Additionally, it is the first capture report of this species in Colombia by artisanal fishery and at shallower catch depths than those reported in previous records. Due to the little existing knowledge about the biology of this species in the country, information on the reproductive biology of the captured individuals is provided.
\end{abstract}

Keywords: Squalus cubensis; Shark; Squalidae; Cuban dogfish; Isla Fuerte.

\section{Introduction}

The Cuban dogfish Squalus cubensis (Howell Rivero, 1936) inhabits the subtropical Atlantic Ocean from North Carolina to southern Brazil and Argentina, including the greater Caribbean and the Gulf of Mexico (Compagno, 1984, 2002; Monzini, 2006; Jones et al., 2013; Brooks et al., 2015). Schools are probably present below 100 $\mathrm{m}$ in the Portobelo area (Panama, Caribbean Coast, Colon Province) and in the San Andres archipelago area (Monzini, 2006).

The Cuban dogfish is a bottom-dwelling species that inhabits deep warm temperate and tropical waters of the outer continental shelf and uppermost slopes, and is found on or near the bottom in large dense schools. Reported capture depths vary between 60 and 730.6 m (Compagno, 1984; Castro, 2011; Jones et al., 2013, Brooks et al., 2015). This species may form large schools of same-sex and size individuals (Castro, 2011) and is never found in surface waters. Juvenile Cuban dogfishes reside in shallow waters along the continental shelf and mature specimens are found in deep waters (Compagno 1984, 2002).

Little information is known about this species and separate catch statistics are not reported for any population. Information available refers to $S$. cubensis as by-catch of artisanal and commercial fisheries in the Caribbean, mainly caught in the northern Gulf of Mexico, although details are lacking and this species cannot be assessed beyond Data Deficient (IUCN Red List) at present (Monzini, 2006). 


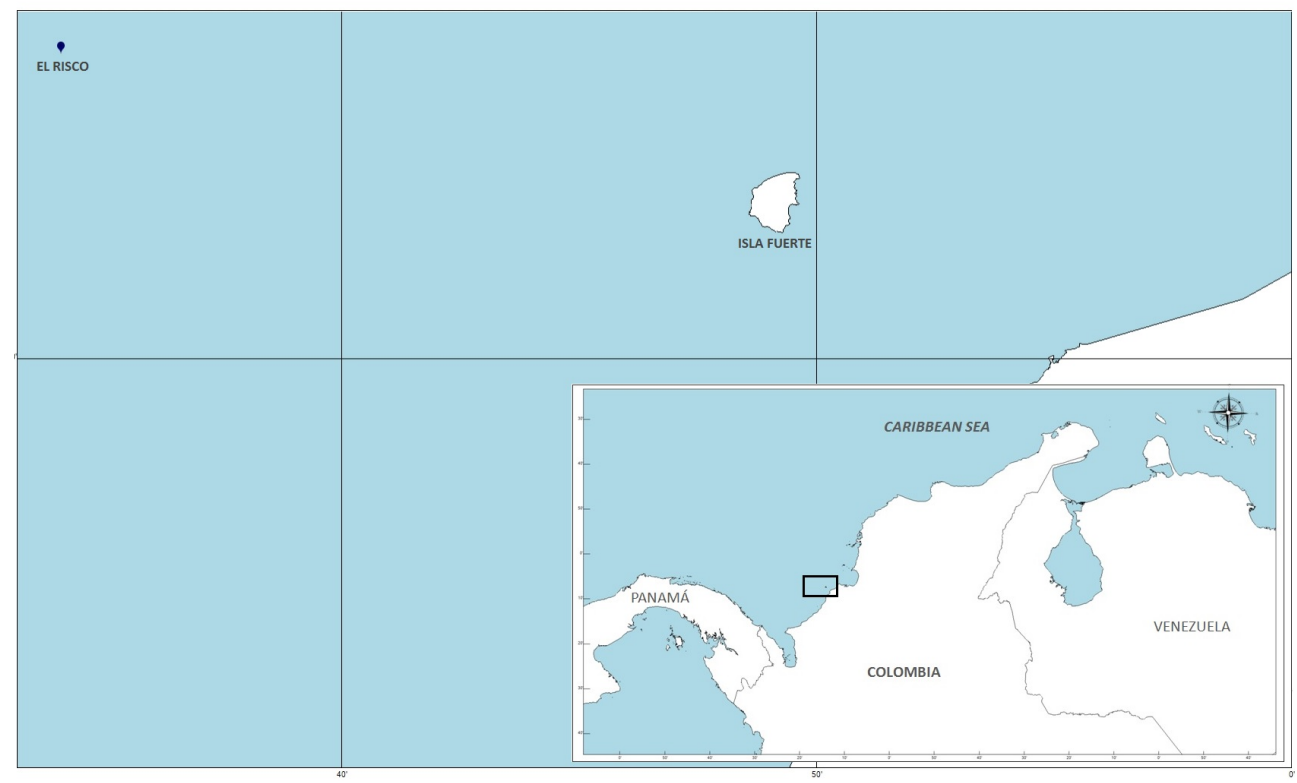

Fig. 1. Geographic location of the site of capture of Squalus cubensis off Isla Fuerte, Colombia.

Previous records have reported the presence of the Cuban dogfish in Colombia only through industrial fishery studies and experimental trawl surveys (Rey-Carrasco \& Acero (1988) in the continental slope of the northeastern coast; Puentes et al. (2009) in the San Andrés archipelago; and Paramo et al. (2012, 2015) across the Colombian Caribbean.

The present article describes two females captured in the southern continental shelf of the Colombian Caribbean (Figure 1), becoming the first record of this species in the area. Furthermore, some characteristics of its reproduction are described in order to provide additional information to the basic knowledge of the species.

The recording of morphometric measures was made point-to-point on the fresh specimens, using a measuring tape and a caliper, following Compagno (1984, 2001, and 2002). For pregnant females, number of embryos in utero and their sex, location (left or right uterus), and total length of each embryo $\left(L_{\mathrm{TE}}\right)$ were recorded (Braccini et al., 2006).

The specimens were preserved in 5\% formaldehyde, transferred to $70 \%$ alcohol and deposited under the catalog number MPUJ 7875 in the Museum of Natural History of the Pontificia Universidad Javeriana, in Bogotá-Colombia.

\section{Results and discussion}

Squaliformes Compagno, 1973

Squalidae Blainville, 1816

Squalus Linnaeus, 1758

Squalus cubensis Howell Rivero, 1936. Proc.Boston Soc.Nat.Hist., 41(4): 45, pls.10 and 11 (Figure 2). 


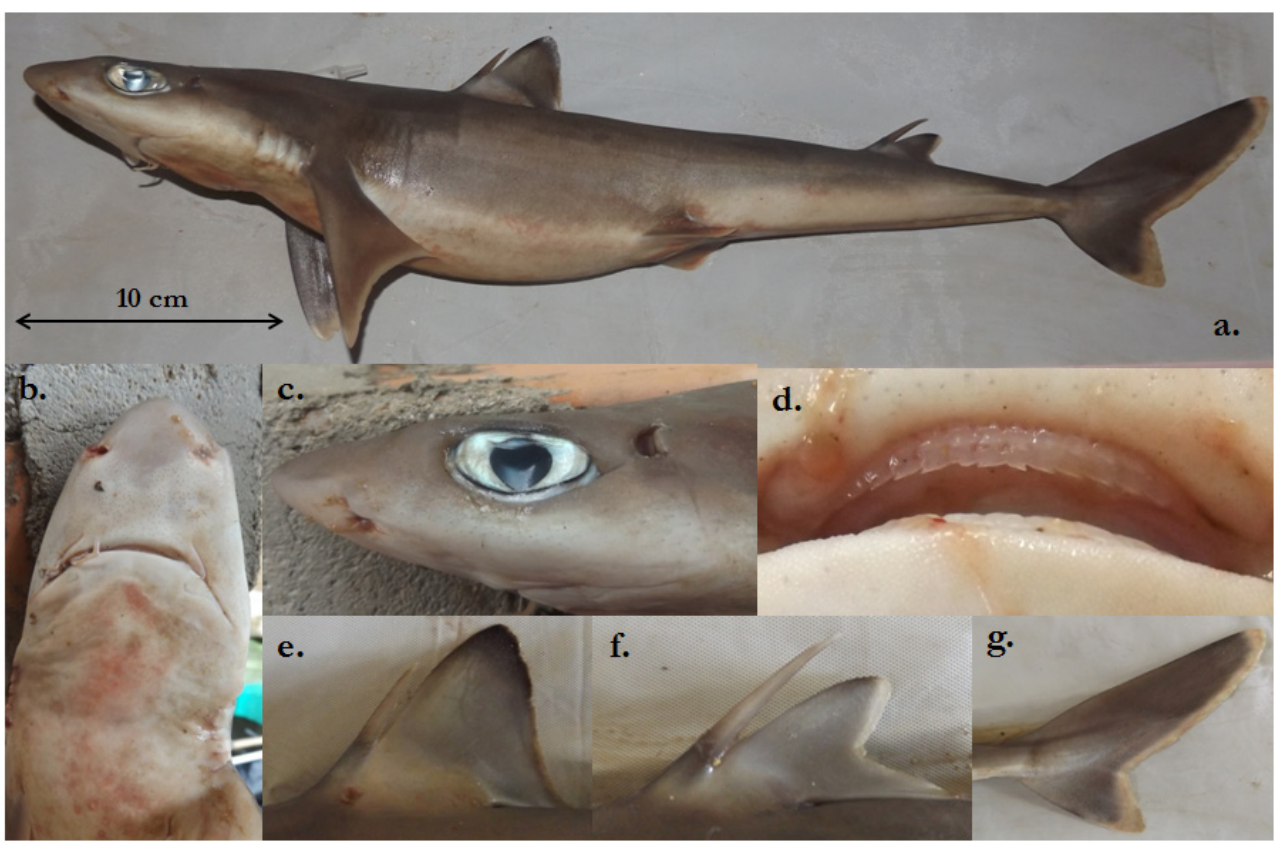

Fig. 2. Female of Squalus cubensis $51.7 \mathrm{~cm}$ LT. a. Side view. b. Ventral view of the head. c. Detail of the eye and spiracle. $\mathbf{d}$. Detail of the upper teeth. e. First dorsal fin. f. Second dorsal fin. g. Caudal fin.

On 25 September 2014, two adult females (MPUJ 7875) were captured by artisanal fishermen through longline fishing in the limit of the southern continental shelf of the Colombian Caribbean, $27 \mathrm{~km}$ off Isla Fuerte and $40 \mathrm{~km}$ off the continental coastline at 100 meters depth, at the fishing locality named El Risco $\left(9^{\circ} 26^{\prime} 25.72^{\prime \prime} \mathrm{N}\right.$, $76^{\circ} 25$ '55. 82" W). The record of these two females constitutes the first report of this species in the southern continental shelf, extending its distribution range to the southern Caribbean Sea. Table 1 shows the morphological measurements taken on both specimens.

The total length $\left(51.7\right.$ and $50 \mathrm{~cm} L_{\mathrm{T}}$ ) is larger than previous records in Colombian waters: $29.5 \mathrm{~cm} L_{\mathrm{T}}$ northeastern coast of Colombia (Rey-Carrasco \& Acero 1988). Currently, there is no additional information about the size of $S$. cubensis in Colombia. For other locations in the Caribbean (Jamaica, Bahamas, Gulf of Mexico and Venezuela) the size ranges vary between 21.2 and $80 \mathrm{~cm} L_{\mathrm{T}}$ (McLaughlin \& Morrissey, 2004; Jones et al., 2013; Tagliafico et al., 2014; Brooks et al., 2015).

In Colombia, the Cuban dogfish has been reported in depth ranges of 270-630 m (Rey-Carrasco \& Acero, 1988) and 246-388 m (Paramo et al. 2012, 2015). Other records in the Caribbean show depth ranges between 198.11 and $913 \mathrm{~m}$ (McLaughlin \& Morrissey, 2004; Jones et al., 2013; Brooks et al., 2015). Our report constitutes the shallowest depth record for this species in the area: $100 \mathrm{~m}$ depth. According to Brooks et al. (2015), the variation in depth is attributable to geographical variation in thermal profiles of the water column; they suggest that $S$. cubensis select vertical habitats based on thermal rather than barometric or photic preferences leading to the disparate depth ranges in different latitudes. 
Table 1. Morphometric characters of the two females (MPUJ 7875) and other references of Squalus cubensis in the area.

\section{PRESENT STUDY}

\section{MEASURAMENT}

\section{Female 1}

\section{$51.7 \mathrm{~cm}$}

$89.4 \%$

$80.3 \%$

$63.8 \%$

$30.0 \%$

$21.7 \%$

$18.0 \%$

$7.0 \%$

$21.9 \%$

$48.4 \%$

$25.9 \%$

$8.5 \%$

$22.8 \%$

$27.5 \%$

$3.1 \%$

$8.7 \%$

$4.4 \%$

$2.3 \%$

$5.8 \%$

$13.2 \%$

$10.6 \%$

$12.4 \%$

$13.5 \%$

$10.1 \%$

$7.2 \%$

$7.2 \%$

$6.4 \%$

$9.7 \%$

$6.2 \%$

$2.7 \%$

$4.6 \%$

$3.1 \%$

$7.7 \%$

$11.8 \%$

$9.1 \%$

$20.7 \%$

$6.2 \%$

$15.9 \%$
Female 2

\section{$50 \mathrm{~cm}$}

$88.4 \%$

$80.4 \%$

$66.0 \%$

$31.0 \%$

$21.0 \%$

$17.0 \%$

$6.8 \%$

$21.0 \%$

$48.0 \%$

$29.0 \%$

$11.0 \%$

$23.2 \%$

$27.8 \%$

$3.4 \%$

$9.0 \%$

$4.6 \%$

$2.4 \%$

$4.0 \%$

$11.4 \%$

$11.6 \%$

$11.4 \%$

$14.0 \%$

$9.0 \%$

$8.0 \%$

$7.0 \%$

$6.0 \%$

$9.8 \%$

$6.0 \%$

$2.8 \%$

$4.4 \%$

$4.0 \%$

$8.4 \%$

$11.0 \%$

$8.4 \%$

$21.0 \%$

$5.0 \%$

$16.0 \%$ 


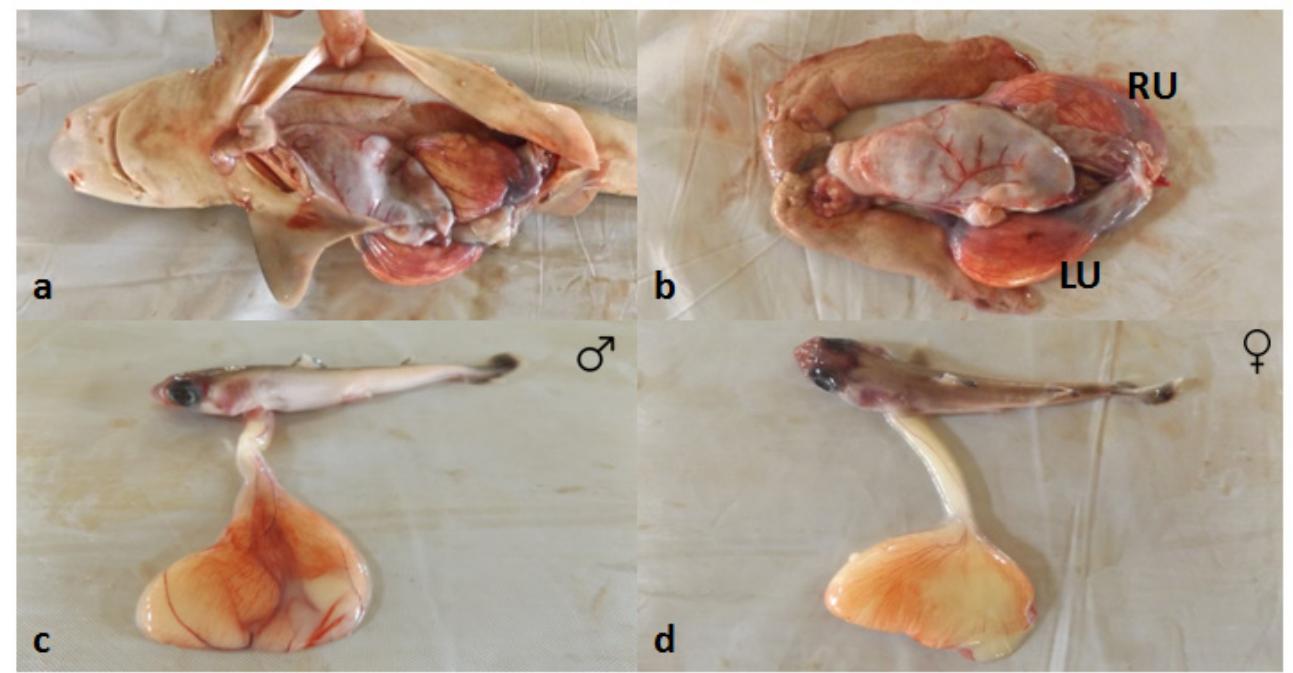

Fig. 3. Female 1. a. View of internal organs. b. RU-Right uterus and LU-Left uterus with candle inside. c. Male mid-term embryo with large external yolk sac. d. Female mid-term embryo with large external yolk sac.

Female 1 (Figure 3): Mature specimen with embryos macroscopically visible in utero. Right uterus with candle contained one mid-term embryo (male $10.2 \mathrm{~cm} L_{\mathrm{TE}}$ ), with a large external yolk sac, small follicles, and enlarged oviducal gland. Left uterus with candle contained one mid-term embryo (female $10.6 \mathrm{~cm} L_{\mathrm{T}}$ ) and a large external yolk sac, small follicles, and enlarged oviducal gland (Table 2).

Table 2. Size and sex of the offspring of the two females of Squalus cubensis (MPUJ 7875).

\begin{tabular}{cccccc}
\hline & $\begin{array}{c}\text { Total Length } \\
\text { Female Lт }(\mathbf{c m})\end{array}$ & Uterus & \# Embryos & Embryo Sex & $\begin{array}{c}\text { Total Length } \\
\text { Embryos Lte }(\mathbf{c m})\end{array}$ \\
\hline \multirow{2}{*}{ Female 1} & 51.7 & Right & 1 & Male & 10.2 \\
Female 2 & 50 & Left & 1 & Female & 10.6 \\
& & Right & 1 & Unknown & 2.2 \\
\hline
\end{tabular}

Female 2 (Figure 4): Mature specimen with embryos macroscopically visible in utero. Right uterus with candle contained one embryo at an early stage of development $(2.2$ $\left.\mathrm{cm} L_{\mathrm{TE}}\right)$ and a large external yolk sac, small follicles, and enlarged oviducal gland. Left uterus empty and expanded, developing follicles, and enlarged oviducal gland (Table 2).

The females of the Cuban dogfish, as other dogfish sharks, are asynchronous breeders in which ovulation, parturition, and mating do not occur at any particular time of the year (Braccini et al., 2006). According to Castro (2011), females mature at $49-50 \mathrm{~cm}$ and the pups are born at $25-27 \mathrm{~cm}$. Jones et al. (2013), estimated that during the maturation process of females, the oviducal glands width begins at approximately $42 \mathrm{~cm} L_{\mathrm{T}}$, followed by development of the uterus at approximately 46 $\mathrm{cm} L_{\mathrm{T}}$, estimating the size-at-maternity at $47.8 \mathrm{~cm} L_{T}$, and suggested that the size-atbirth is approximately $20 \mathrm{~cm} L_{T}$. 


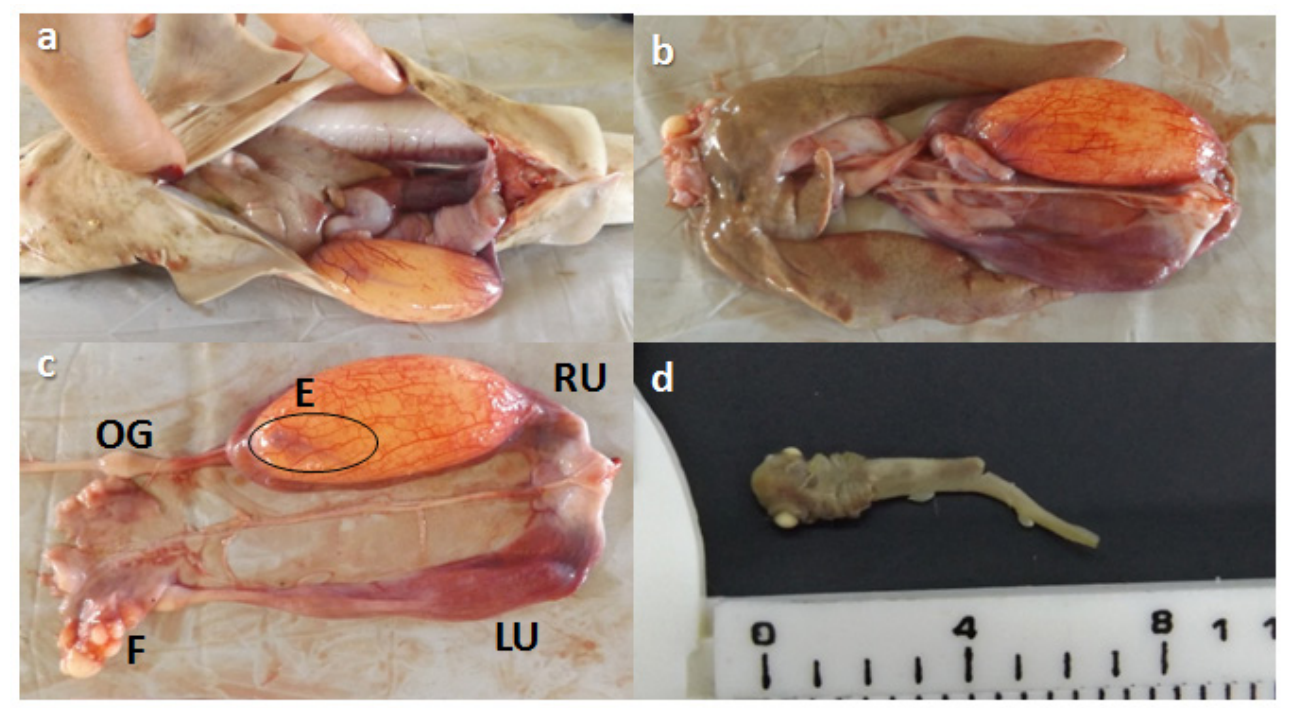

Fig. 3. Female 2. a - b View of internal organs. c. RU-Right uterus with candle inside, LU-Left uterus empty and enlarged, OG-Oviducal gland, F-Follicles, E-Embryo with a very large external yolk sac. d. Early stage embryo.

The two females reported here have similar lengths and showed different stages in the development of their embryos (mid-term and early stage of development) which is consistent with the long gestation period observed in the family Squalidae (Conrath \& Musick, 2012).

In the Caribbean Sea and adjacent waters, information related to the biology and fisheries of sharks is scarce or non-existent. Tagliafico et al. (2014) estimated the length-mass relationship of 21 species of elasmobranchs in Venezuela, and S. cubensis showed an isometric growth. There is no information about biological parameter regarding the Cuban dogfish in Colombia and the little existing information is limited to specific capture records (Puentes et al. 2009).

Overfishing in shallow waters surrounding Isla Fuerte and the consequent reduction of fish populations has forced fishermen to expand their fishing areas and increase the deep sea artisanal fishery. This pressure in deep-waters may have a negative effect in sharks, particularly S. cubensis. It is important to obtain more biological data on this species by monitoring its catches to determine the population status in the area for its conservation and fishery management.

\section{Acknowledgments}

The authors are grateful to G. Orozco for proofreading the translation of the manuscript and to the Shark Research Group of the Pontificia Universidad Javeriana for its support.

\section{Conflict of interest}

Authors declare that there are no conflicts of interest related to the results obtained in this investigation. 


\section{References}

Braccini JM, Guillanders MB, Walker TI. Determining reproductive parameters for population assessments of chondrichthyan species with asynchronous ovulation and parturition: piked spurdog (Squalus megalops) as a case study, Marine and Freshwater Research, 57(1): 105-119, 2006. doi: 10.1071/MF05076

Brooks EJ, Brooks AML, Williams S, Jordan LKB, Abercrombie D, Chapman DD, HoweyJordan LA, and Grubbs DR. First description of deep-water elasmobranch assemblages in the Exuma Sound, The Bahamas, Deep-Sea Research Part II: Topical Studies in Oceanography, 115:81-91, 2015.

doi: 10.1016/j.dsr2.2015.01.015

Castro JI. The sharks of North America. Oxford University Press. 2011.

Compagno LJV. FAO Species catalogue. Vol. 4. Sharks of the world. An annotated and illustrated catalogue of shark species known to date. Part 2. Carcharhiniformes, FAO Fisheries Synopsis, (125) Vol.4, Pt2: 251-655, 1984.

Compagno LJV. Sharks of the world. An annotated and illustrated catalogue of shark species known to date. Volume 2. Bullhead, mackerel and carpet sharks (Heterodontiformes, Lamniformes and Orectolobiformes). FAO Species Catalogue for Fishery Purposes. No. 1, Vol. 2. Rome, FAO. 269 p. 2001.

Compagno LJV. Sharks. In: The living marine resources of the western central Atlantic. Vol. 1. Introduction, mullusks, crustaceans, hagfish, sharks and chimaeras. FAO Species Identification Guide for Fishery Purpose and American Society of Ichthyologist and Herpetologist. Rome. 600 p. 2002.

Conrath CL, Musick JA. Reproductive Biology of Elasmobranchs. In Carrier C, Musick JA, Heithaus MR, editors. Biology of Sharks and their Relatives. Second edition. CRC Press, Boca Raton, Florida, 291-311, 2012.

Jones LM, Driggers III WB, Hoffmayer ER, Hannan KM. Reproductive biology of the Cuban Dogfish in the Northern Gulf of Mexico. Marine and Coastal Fisheries: Dynamics, Management, and Ecosystem Science. 5(1): 152-158, 2013.

doi: $10.1080 / 19425120.2013 .768572$

McLaughlin DM, Morrissey JF. New records of elasmobranchs from de Ciman Trench, Jamaica. Bulletin of Marine Science, 75(3): 481-485, 2004.

MonziniJ. Squaluscubensis. The IUCNRedList of Threatened Species 2006: e.T61416A12476876. doi: 10.2305/IUCN.UK.2006.RLTS.T61416A12476876.en

Paramo J, Pérez D, and Acero A. Estructura y distribución de los condrictios de aguas profundas en el Caribe colombiano, Latin American Journal of Aquatic Research, 43(4): 691699, 2015.

doi: 10.3856/vol43-issue4-fulltext-8

Paramo J, Wolff M, and Saint-Paul U. Deep-sea fish assemblages in the Colombian Caribbean Sea, Fisheries Research, 125 - 126: 87 - 98, 2012.

doi: 10.1016/j.fishres.2012.02.011

Puentes V, Navia AF, Mejía-Falla PA, Caldas JP, Diazgranados MC, Zapata Padilla LA, editores. Avances en el conocimiento de tiburones, rayas y quimeras de Colombia. Fundación SQUALUS, Ministerio de Ambiente Vivienda y Desarrollo Territorial, Instituto Colombiano Agropecuario, COLCIENCIAS, Conservación Internacional, WWF Colombia. 245 p. 2009.

Rey-Carrasco I, Acero A. New records of cartilaginous fishes from de Colombian Caribbean. Actualidades Biológicas, 17(63): 36-39, 1988.

Tagliafico A, Rago N, Rangel MS. Length-Weight Relationships of 21 species of Elasmobranchii from Margarita Island, Venezuela, Journal of Research in Biology, 4(7): 1458-1464, 2014. 
Nuevo registro de Squalus cubensis Howell Rivero, 1936 (Chondrichthyes, Squalidae) en Colombia

Resumen. Dos especímenes de tiburón galludo cubano, Squalus cubensis (Squalidae), se registraron por primera vez en el área de influencia de Isla Fuerte, localizada en el límite de la plataforma continental sur del Caribe Colombiano. Se trata, además, del primer reporte de captura de la especie en Colombia por medio de pesca artesanal a profundidades menores de las reportadas anteriormente. Para contribuir al conocimiento, hasta ahora escaso, acerca de la biología de esta especie en el país, se proporciona información sobre la biología reproductiva de los individuos capturados.

Palabras clave: Squalus cubensis; tiburón; Squalidae; tiburón galludo cubano; Isla Fuerte.

Novo registro de Squalus cubensis Howell Rivero, 1936 (Chondrichthyes, Squalidae) em Colômbia

Resumo. Reporta-se por primeira vez a presença de dois indivíduos de Cação-Bagre Squalus cubensis (Squalidae) na área de influência da Isla Fuerte, uma ilha localizada no limite da plataforma continental sul do Caribe Colombiano. Adicionalmente, este é o primeiro relato de captura dessa espécie em Colômbia por meio de pesca artesanal e a uma profundidade de captura menor do que as reportadas anteriormente. Devido ao pouco conhecimento existente sobre a biologia desta espécie no país, se aporta informação sobre a biologia reprodutiva dos indivíduos capturados.

Palavras-chave: Squalus cubensis; Tubarão; Squalidae; Cação-Bagre; Isla Fuerte.

Diana María Orozco-Velásquez

Biologist with emphasis on marine ichthyology, sharks and artisanal fisheries. Currently, she works as a consultant in offshore fishing studies in the Colombian Caribbean, and as a writer of books about environment and conservation.

Fabio Gómez-Delgado MSc

Research Professor, Master in Environmental Management with emphasis on marine ecosystems and resources. His main research interest is directed to the ecological aspects of marine ecosystems and the relationship between his and characteristics of species of sharks, with emphasis on essential areas. In recent years he has devoted his efforts to the definition of these areas as a strategy for conservation of sharks in the Colombian Caribbean. 